\title{
PENGARUH MINAT BELAJAR DAN PENGUASAAN KOSAKATA TERHADAP KEMAMPUAN MENULIS KARANGAN NARASI SISWA (Survey di SMA Bina Darma Jakarta Timur)
}

\author{
Maman Paturahman \\ Program Studi Pendidikan Bahasa Indonesia \\ Fakultas Bahasa dan Seni Universitas Indraprasta PGRI \\ maman.patur90@gmail.com
}

\begin{abstract}
Abstrak
Tujuan penelitian ini adalah untuk mengetahui seberapa besar pengaruh minat belajar dan penguasaan kosakata secara bersama-sama terhadap kemampuan menulis karangan narasi siswa kelas X di SMA Bina Darma Jakarta Timur. Metode penelitian yang digunakan dalam penelitian ini adalah metode survey dengan analisis korelasional. Sedangkan data dan informasi di lapangan dijaring dengan bantuan kuesioner. Berdasarkan analisis data dapat disimpulkan bahwa: 1) Hasil pengujian hipotesis pertama diperoleh kesimpulan bahwa terdapat pengaruh yang signifikan minat belajar terhadap kemampuan menulis karangan narasi siswa. Hal itu berdasar pada koefisien determinasi diperoleh sebesar 0,664 sedangkan $\mathrm{t}_{\text {hitung }}$ sebesar 11,154. Adapun hubungan regresi bersifat linier karena diperoleh $\mathrm{F}_{\text {hitung }}$ sebesar 124,414. 2) Hasil pengujian hipotesis kedua diperoleh kesimpulan bahwa terdapat pengaruh yang signifikan penguasaan kosakata terhadap kemampuan menulis karangan narasi siswa. Hal itu berdasar pada koefisien determinasi diperoleh sebesar 0,489 sedangkan $t_{\text {hitung }}$ sebesar 7,786. Adapun hubungan regresi bersifat linier karena diperoleh $F_{\text {hitung }}$ sebesar 60,337. 3) Hasil pengujian hipotesis ketiga diperoleh kesimpulan bahwa secara bersama-sama terdapat pengaruh yang tidak signifikan variabel bebas minat belajar $\left(\mathrm{X}_{1}\right)$ dan penguasaan kosakata $\left(\mathrm{X}_{2}\right)$ terhadap variabel terikat kemampuan menulis karangan narasi siswa $(\mathrm{Y})$ dengan koefisien determinasi sebesar 0,755 .
\end{abstract}

Kata Kunci: minat belajar, penguasaan kosakata, dan menulis karangan narasi

\section{PENDAHULUAN}

Keterampilan menulis dan berbicara disebut keterampilan produktif, sedangkan keterampilan menyimak dan membaca disebut keterampilan reseptif. Berdasarkan keempat keterampilan tersebut, menulis adalah salah satu keterampilan yang paling sukar dibandingkan keterampilan berbahasa lainnya. Hal ini terbukti dari banyaknya siswa, dan kalangan lain yang masih lemah dalam keterampilan menulis.

Memahami kenyataan tersebut, pembelajaran menulis bagi siapapun harus digalakkan sedini mungkin yakin dengan memberikan stimulus yang dapat menumbuhkan imajinasi dan daya nalar kepada mereka khususnya anak-anak. Begitu pun pembelajaran menulis bagi siswa sekolah menengah, frekuensi dan intensitasnya harus mendapat perhatian serius dari guru. Semakin sering siswa berlatih menulis, maka ia akan semakin terbuka dalam mencapai keterampilan menulis tersebut. 
Oleh karena itu, guru dituntut untuk memiliki sejumlah kompetensi profesional yakni seperangkat pengetahuan, kemampuan dan keterampilan yang berkaitan dengan pelaksanaan tugas profesional. Adapun tugas-tugas profesional guru tersebut pada umumnya, meliputi kemampuan dalam merancang program pembelajaran, kemampuan dalam melaksanakan program dan mengelola proses pembelajaran, menyelenggarakan penilaian (evaluasi), menyelenggarakan remedial (remedial teaching), dan menyelenggarakan pengayaan (enrichment). Hal tersebut karena disadari bahwa guru memilih peranan strategis atas sukses tidaknya proses pembelajaran di sekolah.

Berkaitan dengan pelaksanaan program pembelajaran (proses belajar mengajar), guru dituntut untuk terampil dalam mengorganisasi kelas, mengatur strategi pembelajaran, mampu mengenali (assessment) siswa, serta menggunakan media dan metode yang tepat. Dalam konteks ini, guru perlu membelajaran berbagai aspek kebahasaan bagi siswa dengan mengerakkan sejumlah kompetensi profesional yang dimilikinya. Salah satu aspek kebahsaan dimaksud adalah penguasaan kosakata. Hal itu penting khususnya dalam keterampilan menulis. Mengembangkan gagasan, menyampaikan pesan, mengkomunikasikan pikiran dan persaan, menguraikan konsep dan lain-lain pada dasarnya diperlukan pengusaan kosakata.

Pada sisi lain keterampilan menulis siswa ditententukan oleh banyak faktor, namun secara umum ditentukan oleh faktor internal siswa dan faktor eksternal. Faktor internal berkaitan dengan kondisi psikologis siswa; motivasi, minat, perhatian, bakat, tingkat kecerdasan, serta kondisi fisikis secara ketegangan (tonus) dan lain-lain. Adapun faktor eksternal berkaitan dengan kompetensi guru, kurikulum, sarana belajar (instrumental input), serta lingkungan dimana siswa tumbuh dan berkembang (environmental input). Oleh karena itu jelaslah bahwa minat belajar dapat menentukan keterampilan menulis siswa. Minat dapat menentukan intensitas dan frekuensi latihan menulis yang pada akhirnya mereka terampil dalam menulis.

Kenyataan di lapangan seperti yang diketahui oleh peneliti saat melakukan studi penjajakan (entry research) diperoleh kesimpulan bahwa: 1) kemampuan menulis siswa belum optimal dan belum merata, 2) minat belajar siswa dalam menulis masih rendah, dan 3) penguasaan kosakata (diction of choise) belum baik atau masih kurang. Kenyataan bahwa keterampilan menulis siswa belum optimal dan belum merata, tampaknya lebih disebabkan oleh beberapa hal dan di antaranya: guru kurang memotivasi siswa dalam menulis, guru jarang memeriksa, menilai, dan mengumumkan nilai menulis siswa, guru tidak pernah memanfaatkan hari-hari besar agama atau nasional dan event-event tertentu dengan memberikan tugas menulis kepada siswa, guru tidak pernah menyelenggarakan lomba-lomba menulis tingkat kelas di sekolah.

Begitu pun penguasaan siswa atas kosakata baku dan asing masih lemah, hal ini tampak dari banyaknya kesalahan siswa dalam penggunaan kosakata saat bertutur atau saat menulis. Penggunaan atau pemilih kosakata banyak yang tidak sesuai dengan konteks. Hal ini adalah gambaran dari belum berhasilnya guru dalam proses pembelajaran kosakata bagi para siswa. Sedangkan masih rendahnya minat belajar siswa dalam menulis tampak dari beberapa sikap dan perilaku siswa saat mendapat tugas menulis yakni: tidak menunjukkan semangat, miskin gagasan, mengabaikan kaidah penulisan, terkesan "setengah hati", mengeluh, dan lain-lain.

Uraian di atas adalah kasus siswa di sekolah saat pembelajaran menulis berlangsung. Ternyata, terdapat dua variabel penting yang mempengaruhi kelemahan menulis siswa yakni minat belajar mereka yang masih lemah dan penguasaan kosakata serta aspek kebahasaan lainnya yang juga lemah. Atas dasar itu, untuk mengawali proses 
penelitian selanjutnya peneliti merumuskan sebuah judul yaitu: "Pengaruh Minat Belajar dan Penguasaan Kosakata Terhadap Kemampuan Menulis Karangan Narasi Siswa di SMA Bina Darma Jakarta Timur”.

\section{METODE PELAKSANAAN}

Metode penelitian yang digunakan dalam penelitian ini adalah motode survei dengan analisis korelasional. Artinya data dijaring dengan bantuan kuesioner. Dalam penelitian ini instrumen untuk mengangkat data ketiga variabel yang diteliti menggunakan bantuan kuesioner. Populasi dalam penelitian ini adalah para siswa kelas X di SMA Bina Darma Jakarta Timur sebanyak 262 orang. Karena jumlah populasi cukup besar, maka peneliti menentukan untuk mengambil sampel 25\% dari jumlah sampel yakni sebanyak 65 orang siswa SMA Bina Darma Jakarta Timur yang dipilih sebagai sampel dalam penelitian ini.

Adapun teknik pengambilan sampel yang digunakan adalah teknik acak sederhana (simple random sampling), yaitu prosedur pengambilan sampel dimana semua individu yang masuk dalam kategori populasi mempunyai kesempatan (propability) yang sama untuk terpilih menjadi sampel. Sebelum dilakukan acak sederhana, ditempuh cluster sampling di mana yang dipilih bukanlah individu-individu melainkan terlebih dahulu dipilih cluster atau sekelompok individu yang secara alami berada dalam satu tempat.

Instrumen penelitian variabel bebas dikembangkan dalam bentuk kuesioner model skala Likert yang mengukur minat belajar, penguasaan kosakata, dan kemampuan menulis karangan narasi pada SMA Bina Darma Jakarta Timur. Pengembangan kuesioner dengan pertimbangan: (a) penentuan indikator dan kisi-kisi variabel, (b) pembuatan kumpulan pernyataan beserta taraf skala, (c) dikonsultasikan kepada dosen pembimbing, kemudian (d) diujicobakan untuk menentukan validitas empirik dan reliabilitas.

Instrumen penelitian dijabarkan berdasarkan indikator-indikator yang dikemukakan para ahli. Indikator variabel yang dijabarkan adalah tes minat belajar $\left(\mathrm{X}_{1}\right)$, penguasaan kosakata $\left(\mathrm{X}_{2}\right)$, dan kemampuan menulis karangan argumentasi $(\mathrm{Y})$. Ketiga tes tersebut dirancang oleh peneliti berdasarkan ciri-ciri minat belajar, kemampuan kosakata dan keterampilan menulis karangan persuasi seperti dikemukakan oleh para ahli.

\section{HASIL DAN PEMBAHASAN}

Merujuk pada hasil analisis pengaruh minat belajar dan penguasaan kosakata terhadap kemampuan menulis karangan narasi siswa pada SMA Bina Darma Jakarta Timur, maka selanjutnya perlu dibahas eksistensi masing-masing variabel sebagai berikut:

\section{Pengaruh Minat Belajar Terhadap Kemampuan Menulis Karangan Narasi Siswa}

Berdasarkan hasil penelitian yang dilakukan terbukti bahwa terdapat pengaruh minat belajar terhadap kemampuan menulis karangan narasi siswa pada SMA Bina Darma Jakarta Timur. Keeratan hubungan antara variabel minat belajar terhadap kemampuan menulis karangan narasi siswa, tercermin pada besarnya nilai koefisien korelasi (r) yang dihasilkan dari perhitungan korelasi antara variabel bebas minat belajar $\left(\mathrm{X}_{1}\right)$ terhadap variabel terikat kemampuan menulis karangan narasi siswa (Y) yaitu sebesar 0,815 . 
Koefisien determinasi atau $\mathrm{R}$ Square sebesar 0,664 adalah pengkuadratan dari koefisien korelasi. Hal ini menunjukkan $66,4 \%$ variabel kemampuan menulis karangan narasi siswa $(\mathrm{Y})$ ditentukan oleh faktor variabel minat belajar siswa $\left(\mathrm{X}_{1}\right)$. Sedangkan sisanya 33,6\% ditentukan faktor-faktor lain.

Berdasarkan perhitungan SPSS 17.0 for Windows, thitung variabel minat belajar yang diperoleh adalah sebesar 11,154 dengan df 63 pada $1 / 2 \square(0,05)$ dipeoleh $t_{\text {tabel }}$ sebesar 1,669 Dengan demikian $t_{\text {hitung }}(11,154)>t_{\text {tabel }}(1,669)$ sehingga jelas $\mathrm{H}_{0}$ ditolak dan $\mathrm{H}_{1}$ diterima.

Hal ini menunjukkan bahwa koefisien regresi variabel minat belajar signifikan terhadap variabel kemampuan menulis karangan narasi siswa pada SMA Bina Darma Jakarta Timur. Dengan bantuan pengolahan data berdasarkan perhitungan SPSS 17.0 tersebut diperoleh $F_{\text {hitung }}$ sebesar 124,414. Sedangkan harga kritis nilai $F_{\text {tabel }}$ dengan derajat bebas pembilang 1 dan penyebut 64 pada $\square(0,05)$ sebesar 3,991.

Dengan demikian, $F_{\text {hitung }}(124,414)>\mathrm{F}_{\text {tabel }}(3,991)$, sehingga jelas $\mathrm{H}_{0}$ ditolak dan $\mathrm{H}_{1}$ diterima. Hal ini menunjukkan bahwa model regresi variabel minat belajar signifikan terhadap variabel kemampuan menulis karangan narasi siswa.

\section{Pengaruh Penguasaan Kosakata Terhadap Kemampuan Menulis Karangan Narasi Siswa}

Berdasarkan hasil penelitian yang dilakukan terbukti bahwa terdapat pengaruh penguasaan kosakata terhadap kemampuan menulis karangan narasi siswa pada SMA Bina Darma Jakarta Timur. Keeratan hubungan antara variabel penguasaan kosakata terhadap kemampuan menulis karangan narasi siswa, tercermin pada besarnya nilai koefisien korelasi (r) yang dihasilkan dari perhitungan korelasi antara variabel bebas penguasaan kosakata $\left(\mathrm{X}_{2}\right)$ terhadap variabel terikat kemampuan menulis karangan narasi siswa (Y) yaitu sebesar 0,699.

Koefisien determinasi atau $\mathrm{R}$ Square sebesar 0,489 adalah pengkuadratan dari koefisien korelasi. Hal ini menunjukkan 48,9\% variabel kemampuan menulis karangan narasi siswa (Y) ditentukan oleh faktor variabel penguasaan kosakata $\left(\mathrm{X}_{2}\right)$. Sedangkan sisanya $51,1 \%$ ditentukan faktor-faktor lain.

Berdasarkan perhitungan SPSS 17.0 for Windows, thitung variabel penguasaan kosakata yang diperoleh adalah sebesar 7,768 dengan df 63 pada $1 / 2 \square(0,05)$ dipeoleh $t_{\text {tabel }}$ sebesar 1,669 Dengan demikian $t_{\text {hitung }}(7,768)>t_{\text {tabel }}(1,669)$, sehingga jelas $\mathrm{H}_{0}$ ditolak dan $\mathrm{H}_{1}$ diterima.

Hal ini menunjukan bahwa koefisien regresi variabel penguasaan kosakata signifikan terhadap variabel kemampuan menulis karangan narasi siswa pada SMA Bina Darma Jakarta Timur. Dengan bantuan pengolahan data berdasarkan perhitungan SPSS 17.0 tersebut diperoleh $F_{\text {hitung }}$ sebesar 60,337 . Sedangkan harga kritis nilai $F_{\text {tabel }}$ dengan derajat bebas pembilang 1 dan penyebut 64 pada $\square(0,05)$ sebesar 4,001.

Dengan demikian, $F_{\text {hitung }}(60,337)>F_{\text {tabel }}(1,669)$, sehingga jelas $\mathrm{H}_{0}$ ditolak dan $\mathrm{H}_{1}$ diterima. Hal ini menunjukkan bahwa model regresi variabel penguasaan kosakata signifikan terhadap variabel kemampuan menulis karangan narasi siswa.

\section{Pengaruh Minat Belajar dan Penguasaan Kosakata Terhadap Kemampuan Menulis Karangan Narasi Siswa}

Berdasarkan hasil penelitian yang dilakukan terbukti bahwa terdapat pengaruh minat belajar dan penguasaan kosakata terhadap kemampuan menulis karangan narasi siswa pada SMA Bina Darma Jakarta Timur. Keeratan hubungan antara variabel minat 
belajar dan penguasaan kosakata terhadap kemampuan menulis karangan narasi siswa, tercermin pada besarnya nilai koefisien korelasi ( $\mathrm{r}$ ) yang dihasilkan dari perhitungan korelasi antara variabel bebas minat belajar $\left(\mathrm{X}_{1}\right)$ penguasaan kosakata $\left(\mathrm{X}_{2}\right)$ terhadap variabel terikat kemampuan menulis karangan narasi siswa $(\mathrm{Y})$ yaitu sebesar 0,869 .

Koefisien determinasi atau $\mathrm{R}$ Square sebesar 0,755 adalah pengkuadratan dari koefisien korelasi. Hal ini menunjukkan $75,5 \%$ variabel kemampuan menulis karangan narasi siswa $(\mathrm{Y})$ ditentukan oleh faktor variabel minat belajar $\left(\mathrm{X}_{1}\right)$ dan penguasaan kosakata $\left(\mathrm{X}_{2}\right)$ sedangkan sisanya $24,5 \%$ ditentukan faktor-faktor lain.

Berdasarkan perhitungan SPSS 17.0 for Windows, $\mathrm{t}_{\text {hitung }}$ variabel minat belajar dan penguasaan kosakata yang diperoleh adalah sebesar 8,189 dengan df 63 pada $1 / 2 \square(0,05)$ dipeoleh $t_{\text {tabel }}$ sebesar 1,669 Dengan demikian $t_{\text {hitung }}(8,189)>t_{\text {tabel }}(1,669)$, sehingga jelas $\mathrm{H}_{0}$ ditolak dan $\mathrm{H}_{1}$ diterima.

Hal ini menunjukkan bahwa koefisien regresi variabel minat belajar dan penguasaan kosakata signifikan terhadap variabel kemampuan menulis karangan narasi siswa pada SMA Bina Darma Jakarta Timur. Dengan bantuan pengolahan data

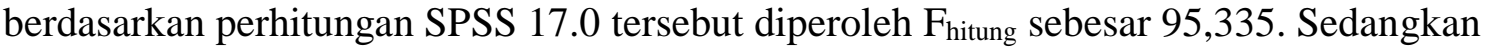
harga kritis nilai $F_{\text {tabel }}$ dengan derajat bebas pembilang 1 dan penyebut 64 pada $\square(0,05)$ sebesar 3,991.

Dengan demikian, $\mathrm{F}_{\text {hitung }}(95,335)>\mathrm{F}_{\text {tabel }}(4,001)$, sehingga jelas $\mathrm{H}_{0}$ ditolak dan $\mathrm{H}_{1}$ diterima. Hal ini menunjukkan bahwa model regresi variabel minat belajar dan penguasaan kosakata signifikan terhadap variabel kemampuan menulis karangan narasi siswa.

\section{SIMPULAN}

Simpulan yang dapat diambil dari penelitian ini adalah sebagai berikut: 1) Hasil pengujian hipotesis pertama diperoleh kesimpulan bahwa terdapat pengaruh yang signifikan minat belajar terhadap kemampuan menulis karangan narasi siswa. Hal itu berdasar pada koefisien determinasi diperoleh sebesar 0,664 sedangkan $t_{\text {hitung }}$ sebesar 11,154. Adapun hubungan regresi bersifat linier karena diperoleh $F_{\text {hitung }}$ sebesar 124,414. 2) Hasil pengujian hipotesis kedua diperoleh kesimpulan bahwa terdapat pengaruh yang signifikan penguasaan kosakata terhadap kemampuan menulis karangan narasi siswa. Hal itu berdasar pada koefisien determinasi diperoleh sebesar 0,489 sedangkan thitung sebesar 7,786. Adapun hubungan regresi bersifat linier karena diperoleh $F_{\text {hitung }}$ sebesar 60,337. 3) Hasil pengujian hipotesis ketiga diperoleh kesimpulan bahwa secara bersama-sama terdapat pengaruh yang tidak signifikan variabel bebas minat belajar $\left(\mathrm{X}_{1}\right)$ dan penguasaan kosakata $\left(\mathrm{X}_{2}\right)$ terhadap variabel terikat kemampuan menulis karangan narasi siswa $(\mathrm{Y})$ dengan koefisien determinasi sebesar 0,755. Hubungan regresi ganda bersifat linier karena diperoleh $F_{\text {hitung }}$ sebesar 95,335. 4) Variabel bebas minat belajar $\left(\mathrm{X}_{1}\right)$ dan penguasaan kosakata $\left(\mathrm{X}_{2}\right)$ baik secara masing-masing maupun bersama-sama memberikan kontribusi yang signifikan terhadap variabel terikat kemampuan menulis karangan narasi siswa (Y).

Kontribusi masing-masing variabel bebas terhadap variabel terikat adalah: Variabel minat belajar sebesar $66,4 \%$ dan variabel penguasaan kosakata sebesar48,9\%. Kontribusi kedua variabel bebas secara bersama-sama terhadap variabel terikat adalah 75,5\%. Dengan diketahuinya sumbangan variabel minat belajar $\left(\mathrm{X}_{1}\right)$ dan penguasaan kosakata $\left(\mathrm{X}_{2}\right)$ sebesar $75,5 \%$ terhadap kemampuan menulis karangan narasi siswa, maka dapat 
diambil kesimpulan bahwa 24,5\% kemampuan menulis karangan narasi siswa disebabkan oleh faktor-faktor lain.

\section{DAFTAR PUSTAKA}

Alwasilah, A. C. (2007). Pengarang Kosakata. Bandung: Angkasa Raya.

Djamarah, S. B. (2006). Psikologi Belajar. Jakarta: PT. Rineka Cipta.

Dimyati, M. (2002). Belajar dan Mata Pelajaran. Jakarta: Rineka Cipta.

Nababan, S. U. S. (2006). Metodologi Pengajaran Bahasa. Jakarta: Gramedia.

Poerwadarminta, W. J. S. (2002). Kamus Umum Bahasa Indonesia. Jakarta: Balai Pustaka.

Razak, A. (2003). Proses Belajar Mengajar. Jakarta: Bumi Aksara.

Slameto. (2005). Belajar dan Faktor-faktor yang Mempengaruhinya. Jakarta: Rineka Cipta.

Sirait, B. (2005). Pedoman Karang-Mengarang. Jakarta: Pusat Pembinaan dan Pengembangan Bahasa.

Syah, M. (2003). Psikologi Belajar. Jakarta: PT. Raja Grafindo Perkasa.

Tarigan. (2006). Menulis Sebagai Suatu Ketrampilan Berbahasa. Bandung: Angkasa.

Winkel, W. S. (2006). Psikologi Pendidikan dan Evaluasi Belajar. Jakarta: Gramedia. 